\author{
御井の風景 \\ 「藤原宮御井歌」にみる風景の構造ＩII \\ LIVED SCENERY : 'HOLLY WELL' IN “FUJIWARA-GU” \\ Scenery-structure in "MANYOH-SYU” poem No. 52 III \\ 香西克彦* \\ Katsuhiko KOHZAI
}

\begin{abstract}
This paper starts with a conviction that "Manyoh-Syu" poem no.52 is a text for the structure of Scenery. It is the last part of the hermeneutic thinking on the poem and the sequel to the previous paper on Scenery of "Yoshino". Considering the meaning of "Mii", or holly well, two places -Yoshino and Fujiigahara- were integrated into the whole Scenery Structure of "Fujiwara-Kyo". In conclusion, the Scenery of "Fujiwara-Kyo" can be an example of the principles that the human being lives in the "Twofold-World".
\end{abstract}

\title{
Keywords: scenery,place,Manyoh-Syu,Yoshino,Fujiwara-Kyo,Twofold-World
}

風景, 場所, 萬葉集, 吉野, 藤原京, 二重世界

\section{1. 序}

『萬葉集』「藤原宮御井歌」に定位し，風景なるものとその現れの構 造を解明せんとする試みである。前稿りに於いて，吉野とはそもそもど のような場所として「生きられ」ていたか，はたまたその吉野は持統 にとってどのような意味を有している場所であるかについてその大略 が，「見え」ない吉野が詠み込まれていることに起動され，第一段階の 考察として整理されたわけである。がしかし、例えば雨乞いの場所と いうだけでは未だ「御井歌」に詠まれてあることの説明にも, 二つの 場所の関係の説明にもなってはいない。再び原点である「御井歌」へ 帰ってみなければならない。

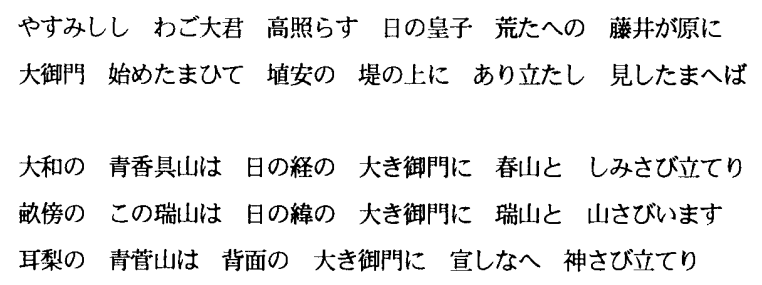

言うまでもなくこの歌は，藤原宮の；そして持統の永遠ならんこと を言祝ぐための歌, 即ち持統讃歌であり, 新宮(京)讃歌であった。そ うした歌の主旨に即した観点からの考察を缺かすわけにはいかないか らである。そして注目すべきはこの新宮の御井を，中心に持ち出して 詠うことに拠って讃歌たり得ているという点である。先の吉野は絶え ることなく流れ続ける川に拠って，その永遠性が願われたのであった が、ここでは汲めども盡きることなく滾々と涌き出したであろう「御 井の清水」の「常」なることを詠むことが，とりもなおさず藤原宮 (京)の常久なることを言祝ぐことなのである。それはこの歌が結論部 である最終段落の最終句「常にあらめ 御井の清水」へ向けて構成さ れていることからも裏付けられようし，そもそもこの歌には「藤原宮 御井歌」という題が付せられていたことを忘れてはならない。このよ うに「井戸」に拠って言祝がれる例は他に見当たらないことであるだ けに注目する必要があろう。

こうした注目のもと, この「御井歌」全体から吉野の意味の第二段 階の考察が展開される。吉野の風景がより明確に結像し，上同時に藤 原京の風景の全体構造が素描されんことが目指されているのである2。

\section{II 、藤原宮の御井}

それではこの藤原宮の御井とはどのような由来を持った井戸なので 
あろうか。「藤原宮に御井があった、といふより、…(略) …、よい井 泉があうたのでそのあたりを藤井が原と呼び、略して藤原ともいひ、 そこを中心に宮殿が営まれ、その宮を藤原の宮と呼んだと見るべきで ある。上代人にとって良水の出る井泉は珍重せられ、そこを中心に宮 が営まれたり聚落が形づくられたりしたのである゙๋」これが従来の藤 原宮(京)及びその御井についての代表的な見解であるのだが, これに対 し「藤原宮周辺の地勢梳、東方と南方が高く、多武峰山系に降った雨 は地下水となって、東と南からここに集まってくる。それも地表の下 の深いところを流れてくれればよいが、香具山の西方一帯は、地下水 の水位が高く、到るところで地下水が湧出して、放置しておくと湿地 帯になってしまうような所であり」り，「このような湿地帯の藤原宮地 に『藤井』と呼ばれるような名泉があったとは考えられない。『藤井』 の名からすれば、井の傍らに藤が自生していたはずであるが、緾つく ベき樹木もない湿地帯の原野に、藤が自生するはずもないのである5う という状況が真相を言い当てているのであれば，藤原宮の御井は宮に 新しく掘られた堀井ということになる。とすれば「御井」そのものに 元々特別な意味があるのではなく，井戸に関して古代人がどのような 観念を抱いていたのであるかが問題とならねばならない。

例によって文献を渉猟するという手続きがここでも有効ではあろう が，それは後に譲ることとして，ここでは宮，しかも新しく造営され た宮, と井の関係を先ず考察しておくべきであろう。と言うのもこの 「御井歌」には作者未詳の,

藤原の 大宮仕へ 生れつくや 娘子がともは ともしきろかも

$$
\text { (巻一一五三). }
$$

という短歌が付されているからである。長歌である「御井歌」とこの 短歌は言うまでもなく一組のものであって「御井歌」のみで論ずるこ とは危険でもあろうからである。歌の意味は「藤原の大宮に打仕えす るために生まれういてきた娘子たちはうらやましいことよ」というほ どのものであろう。この長短歌と照応して類似した八一番歌があるゅ.n。

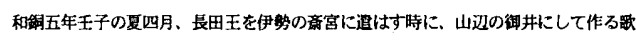

山辺の 御井を見がてり 神風の 伊勢娘子ども 相見つるかも

$$
\text { (巻一一八一) }
$$

類似の光景がそこに詠まれていることが理解されよう。さらに，そ れは越中国の国府でのことではあるが,

もののふの 八十娘子らが 汲みまがふ 寺井の上の 堅香子の花

(卷十九一四一四三)

と大伴家持が詠っていたことが思い出される。国庁の付近には良泉が あり，その井戸の傍らに絶えず水汲みの娘子たちが往来し賬わいをみ せていたのでもあろう。いずれも井と娘子という組み合わせである。 このような萬葉歌が引用された理由はいずれ明らかにされるとして, ここでの問題である五三番歌に戻らなければならない。

五二番歌との関係から，この「大宮仕へ」とは「御井の清水」に奉 仕することであると考えることが適当であると思われる。そしてこの 「御井の清水」には二つの可能性がある。その一は大嘗祭の御井であり, 今一つは祈年祭の御井である。大嘗祭の記録は「天武紀祀」に初出し， 祈年祭のそれは「天智紀9)」に初出する。即ちこれらの祭式儀礼が存在
していたことは確認できるのであるが, その詳細は,『儀式』『延喜式』 や、『江家次第』などの故実書, 公家の日記類といった平安朝の書物に 拠らざるを得ない。当然ながらそれらの書物に記されている祭式や儀 礼は，あくまでも律令制下のものであり，さらに平安朝の変容を考慮 に入れねばならぬものばかりであることは言うまでもない。特に我々 が着目するこの律令制以前の祭祀儀礼の復元にはこのような大きな史 料的制約があるのではあるが, 本稿に関連する限りに於いて敢えてそ の考察を試みてみなければならない。

先ず，大嘗祭の御井が「藤原の御井」であることの可能性から検討 してみよう。䟠祚大嘗祭式(1)』に拠ると，大嘗祭の一連の行事の中で, 御膳御酒を淮備する斎場の造営に於いて, 二処をトして御井を掘り, 謷酒に当つて井の神を祭ることを述べているい。二本の井戸はそれぞ れ神饌・神酒の用水に当てられたが, その一は「御井」, もう一つは 「造酒児井」と名付けられている。この「造酒児井」に係わって造酒児 （造酒童女）という娘子12が重要な役割を果たしているのである。

踐祚大嘗祭には『天神之寿詞』を中臣氏が奏上することが定められ ている(13)。文献上の初見は,「持統紀」四(690)年正月条 ${ }^{14}$ の即位礼, 及 び五年十一月条15jの大嘗祭に於けるものである。藤原宮遷都が持統八 (694)年であることを考えれば, 持統の大當祭の御井と五二番歌の御井 は，とりあえず無関係であると判断しなければならないことになるが, 今暫くここに留まってみよう。

この中臣が奏上する『天神之寿詞』は，神代の物語にことよせて新 帝の即位を祝福するものとしてあったことは, 『令義解』や『令集解』 がこの言葉に注釈して「謂。以_神代之古事_。為_萬壽之寶詞_也」と 記すことからも知られるのであるが，『天神之寿詞』そのものは残念な がら残されてはいない。が, かろうじて平安末期藤原頼長の日記『台 記』の別記に，康治元(1142)年の近衛天皇の大嘗祭の時のものが『中 臣寿詞16』として筆録されたおかげで, 今日その概要を知ることがで きる。「神代之古事」と言われていると思しき神話的伝承部分を要約で 示してみよう。

天棌降臨の際, 天涊雲根が天児屋の命を受け, 神漏岐・神漏 美二神に 会って,「皇孫の御䑅の水として、現し国の水に天つ水を加えて献上した いと申し出た。そこで二神は, 天忍 雲根に玉串を授け, これを地上に 刺し，呪言を唱え「天の八井」が湧き出る方法を教えた。これを「天つ 水」として，神酒・神饌を作ることにしたという。

謂ゆる「天つ水」の神話と呼ばれる部分であり，この部分こそ，本 来の『天神之寿詞』の核心を伝えるものであり, 即位式で奏上された のは, この御养の水, 即ち御井の水に関わるこの部分であると思われ る。ここに言われる「天つ水」が現実的に雨水のことを指すことは, ほほ間違いないと思われる。「雨水を交えた御井の水を、御锶の水とす るということは、御井の水を、天上の聖水と等しからしめんとする呪 術的な試みであ ${ }^{17} 」 り ，$ 先に考察したように残念ながら藤原宮には当 てはまりはしないが, 斎場に掘られた井戸は「天の八井」としてあっ たのであろう。ここではこれ以上考察する暇はないが，この「天つ水 の神話とよく似た神話が，伊勢神宮の末社「御井社」とその井である 「忍穂井」の起源神話として伝えられていることを付記しておこう。 「大王の即位の儀礼に読み上げられる『中臣寿詞』とほぼ同じ詞章が、 大王の最高守護神の御䍻の料の水について語られていたとしても、不

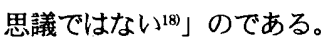


続いて，祈年祭の「御井」である可能性を検討してみよう。『延喜 式 巻一 神祁一』「四時祭上」に拠ると祈年祭は，毎年二月四日神部官 の斎院に於いて，官が奉弊する七百册七座の神々を祭るもので，中臣 が祝詞を読み，忌部が諸社の神主，祝らに弊帛を班給するというもの である。祝詞191は，天つ社・国つ社の皇神たちに，皇孫命の弊帛を奉 る旨を述べた後, 祈念の対象になっている神名を一つ一つ挙げて, 奉 幣の主旨を述べるのであるが，それらの神々の名と順序は，「御年の皇 神等」,「大御巫(神部官の御巫)祭神八座」,「座摩巫祭神五座」,「御門巫 祭神八座のうちの櫛磐間門・豊磐間門二神」「生嶋巫祭神二座」、「伊 勢の天照大神」,「御縣坐六神」,「山口坐六神」,「水分坐四神」である。 磐間門神，山口神，水分神については既に触れたところであるが，こ こで問題となるのは, 『神名帳』に言う, 宮地を領く「宮中神册六座」 の内,「神䄮官西院坐御巫等祭神廿三座」の中の「座摩巫祭神」として の「生井神・福井神・綱長井神201」の三神である。『延喜式』ではこの 祈年祭での御井祭の他にも, 四時祭の御川水祭, 臨時祭として御井祭, 産井祭, 御井並 御䆠祭等の水或いは井戸に関する祭を行うことが規定 されている。「(各々の祭の)詳細はわからないが、.......との中でもつとも 重要なのが座摩巫が執り行う御川水祭で、祈年祭の祭祀の対象となつ ているのも、御川水祭で祭られる生井・栄井・津長井の神であった ${ }^{21} 」$ のである。藤原宮に於ける「御井」の位置はなお不明22)ではあるが, この三神は内裹に掘られた「御井」の神なのである。藤原宮に於いて もこれら『延喜式』に規定される御井の祭が行われていたのであれば, その祭は御川水祭とほぼ同じ形式で行われたものと判断すべきであろ う。決定的な決め手には欠けるものの, これらの祭式は毎年の行事で あり，これらの祭の対象となる三神が坐ます「御井」こそが五二番歌 の「御井」であり，「娘子がとも」とは座摩の巫女融をさし，「大宮仕 へ」とはこれらの神々に仕えることである可能性は高いと言えるので はなかろうか。

以上「御井」に関する祭の考察から、「藤原宮御井」がどのような 性格をもつものであるかについての推定が行われた。だが, 吉野と藤 原という二つの場所の関係と, 吉野がここに詠み込まれていることに ついてはなんらの解答を与える迄には至っていない。これらの問題に 答えるために, ここでの考察から浮かび上がってきた新たな疑問点を 拾い上げておくことが有益であろう。

先ず, 宮廷儀礼の検討から宮殿の「御井」には神が坐ますことが注 目される。座摩巫祭神三座であり，大嘗祭に於いて釀酒に先立って祭 られる神である。『貞嚾儀式出』に扴ると，この時祭られる神は丹生川

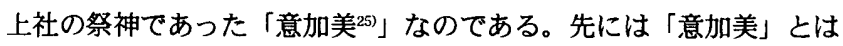
雨乞いの神であったのであるが, そもそもこの「意加美」とは如何な る性質を有した神なのであろうか。そしてどのような理由で, この雨 乞い神たる「意加美」が「御井」と結びついたのであろう。雨雲を名 とする神や雨水が寿詞の中で讃えられていたことと考え合わすなら, ここでもやはり雨乞いということが最重要な意味だということなので あろうか。

次に, 祈年祭の最初の記事は「天智紀」にみられることについては 既に触れたが, その記事には「山御井傍 ${ }^{26} 」$ 即ち, 山麓の井泉が祈年 祭の祭場に選ばれたことが記載されている。これに関し「山麓の井泉 が祈年祭の祭場に選ばれていることは然るべきこと27」であるという 興味を引く言説がある。言わんとするところは井泉の「傍」は全国の 神々を迎えて祭る, 祈年祭に最も相応しい場所と観念されていたとい うことであると思われる。とすれば既に予感されていたように, 重要
なのは「御井」ではなく「井」そのもの,「水」そのもの, そして「井」 に坐す神ではなく, 「井」そのもの, 或いは「井」のある場所なのでは なかろうかという疑問が生じてくるのである。

\section{III. 井泉・境界・水}

これらの疑問に答えるためには，前に保留しておいた文献を渉㷁す るという手綍きの中から井戸, 或いは泉がどのように「生きられ」て いたかを確認する必要があろう。『記紀』や『風士記』の説話の中には, 神聖な井泉の由来が大王に関わるものとして語られるものが少なくは ない。『風土記』から井泉に関わるの説話を拾い出すことは容易である。 『風土記』に集められた「井」に緾わる一連の説話群は, その大半が地 名起源に関わるものであることは周知の如くであるが，それを超えて 「井」の意味そのものを密かに伝えていると思われるものがある。以下 順次それら説話の注目部分の引用を交えながら考察していくこととす る。

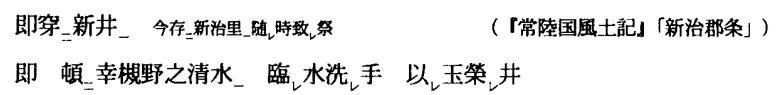

(「常陸国風土記」行方郡条」)

遂到_赤石郡澌御井_供_進御食_故曰_廝御井_

（「播磨国風土記」「贺古郡条」）

地名説話にのみ関わると判断されるものは省略に従うこととするが28, 先ずこの三例からは「井」或いは「井」のほとりで行われたであろう 地方的な祭儀の存在, そして地方首長層が井泉のほとりで祭儀を行う 風習が, 全国各地に普遍的に存在していたことが確認できよう。次に 以下の五例をみてみよう。

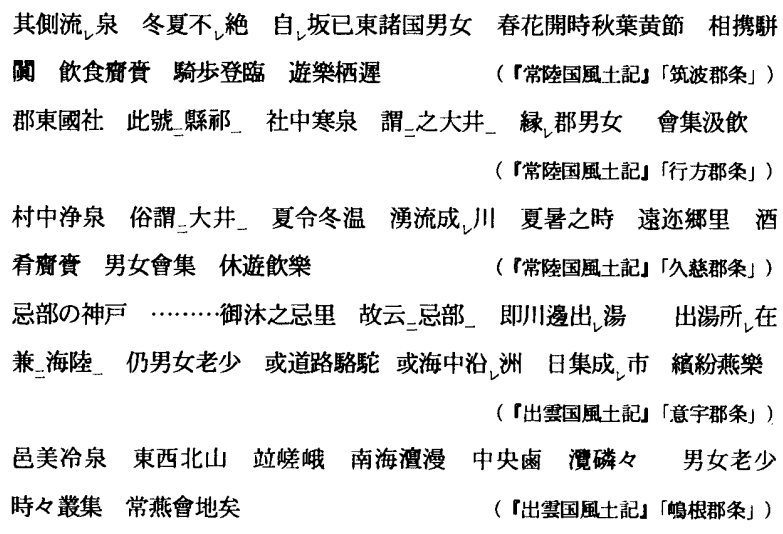

「良水の出る井泉は珍重せられ、そこを中心に宮が営まれたり聚落 が形づくられたりしたのである」と想像されていた光景が, そして先 の家持歌を髧熊させる光影がここにはあろう299。井泉のほとりで別集 団に属する互いに見知らぬ男女が出会い，そこで宴が催される。井泉 のほとりでの男女の宴は農耕儀礼とは無関係にそのまま歌垣の世界へ と慗がり行く。井」に於いて祭が行われ，歌垣が行われたという事実 は，市或いは畧と同様に「井」或いは「井」のほとりが境界領域であ るということを明示するものであろう30。風土記』には「井」が境界 と意識されていたことを思わせる，次のような不思議な話も揭載され ているのである。 
此里此治山頂有，井 其名云_眞奈井 今既成、沼，此井天女八人

降來浴_水

（「風土記逸文」丹後國」）

此村在。井一女 汲、水 即被吸没。故日:號修布。

（「播磨国風土記」賀毛郡条」）

何処からともなく天女が飛び来たり，何処へともなくまた飛び去つ て行く。この話は何処とも知れない場所が知られないながらも天上世 界を想像させるものと言えよう。:それに反し二例目の話はなにか地下 世界を思わせるものであると言えようか。

前節での考察に於いて宮殿の、御井」には神が坐ますと観念されて いたことが確認されたが、『風土記』に於いては如何であろうか。

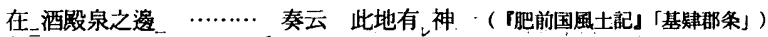

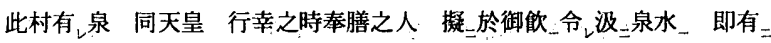

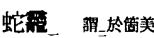

(「豊後国風土記」「直入郡条」)

ここでもやはり「井」には神が坐ますと観念されていたことが理解 される。そしてその神はやはり「於箅美」と呼ばれているのである。 即ち宮殿の御井に坐まし，丹生川上社に坐すあの「オカミ」なのであ

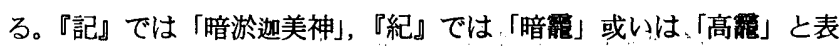
記されて登場する ${ }^{311}$ 。話としてはいずれも血又は剣から化成した神で あるとされているが，大系本頭注が言うように，その神徳は箕谷の水 を掌ることにあろう。また『記紀』ではこの「オカミ」と並んで「暗 御津羽神」「暗罔象」が登場する。この神と丹生川上社の祭神である 「罔象女神」とが同一の神を表すものとは，その生誕の事情 ${ }^{22}$ からして 考え難いが，その本質は類似すると思われる。またこの神について， 大系本頭注は次のように解説する。先ずその名「ミツハ」を「水つ走 (八)」又は「水つ早(八)」かとし，「潅溉用の水を走らせる女神の意であ ろう」とする。また『淮南子』の「汇論訓の注」に「水之精也」とある ことや、『荘子』「達生」に「水有_周象」とあることを紹介し、「圆象』 は水神，また水中の怪物」であり，「圆』は，形をかくして見えない

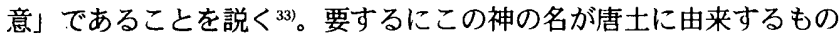
であろうがなかろうが, 井泉の内に，その水の中に，「見え」ないなが ら，怪物或いは霊物，つまり神なるものが潜んでいることが確信され， その人知を超えた正体不明のなにものかを「园象」と名付けていたの である。

乃至_山口_摽梲置_堺堀_告_夜刀神_ 自、此以上 㯖。為_神地。自、 此以下須，作_人田。自、今以後吾為神祝。永代敬祭冀勿 設、社初祭者 神蛇避隠 所。謂其池今號_椎井池_池回椎株 清水所。 出 取、井名、池

（「常陸国風土記」「行方郡条」）

前稿象でも若干触れた有名な夜刀神伝承とその後段である椎井伝承 の一部である。夜刀神伝承では, 神の領域と人間の領域が分節され, その境界である清水の涌き出る山の口に社を設け，以後この夜刀神を 祭ったことが言われる。ここでは省略したがこの伝承の引用以前の部 分に「俗云 謂、蛇為=夜刀神－其形蛇身頭角」と割注されている。即ち， 夜刀神の正体は頭に角のある蛇であることが言われているのであり， 椎井伝承ではこの神は泉にその姿を隠すことが言われるのである。大 三輪の神が水神であり蛇体であったことが思い出されもする。すぐ前 の引用で「オカミ」は「蛇霞」と表記されていることを考え合わせれ
ば，この夜刀神もやはり「オカミ」と呼ばれて然るべきでもあり，こ れが、オカミ」の最も古い形を表すものであると思われる。形を隱し てその姿を現さない水神が蛇に姿を変えて現れると信じられていたの であろう。この伝承では神が祭られる対象として描かれているが，実 は清水が湧き出し，池をなしたこの椎井と名付けられた池そのものが 祭られていたと考えることはできないであろうか。「井に神を祭った場 合、井を支配する神などというような抽象的なものを考えたのではな く、部落民に恩恵を施す井そのものに神を捉えたとしなければならな ( ${ }^{35)}$ 」と考えることは，或いは言い過ぎであるかも知れないが，「井」 そのもの「水」そそののが最重要であるとする考えは当を得ていると 思わ机るからである。阱」や池」を神体とする神社は幾つか存在し ているが，ここでは古代四文献に登場するももう柱の水神「泣澤女神」 と，この神を祭神とし，「井」そのものを神体とする神社について触れ ておかなけ执ばならない。

香久山の北西麓間近: 一般に埴安の池が想定されている辺りに，式 内社畧尾都多本神社がある ${ }^{36} 。 こ の$ 神社が次の萬葉歌に詠われる「泣 沢の神社」に比定されている社である。

或㽜の反歌一首

泣沢の 神社に御酒据总，祈れども，我が大君は：高日知らしぬ

(巻二-二○二)

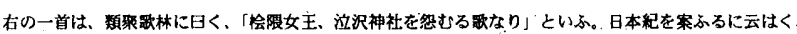

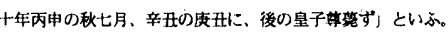

『記紀』神話でばろこの「泣澤女神」は涙になった神であるとされて いるのではあるが,「泣き沢」つまり「鳴く沢」というその名は, 湆を 立てて，水が涌き出している場所に坐す神であることを明快に示して いるものと思われる。さてこの萬葉歌であるが，左注に見る通り，泉 の神に皇子の蘇りを祈ったが，その祈り届かず返って恨み言を言う歌 である。これまでみてきた水の意味は潅激用水・飲料水という実利的 な意味が主であった。そしてここでは触れ得なかったが，裙ぎ・清め の水, 即ち浄化力という意味も水は有していた。人々は水に様々な願 いを託し, 且つ祈ったのであったが, この水神の司る意味はそれまで にない全く新しい意味であると思われる。生命が蘇る，生命を再び誕 生させる。つまり水の神は生命をも司っているのであり，水に託され た新しいこの観念は不老不死，即ち若水，をちみづ (変水) 等に連結 していくのでもあろう。現実的な意味からこのような神秘的な意味ま でもが託されるように変化するのは，勿論歴史的変遷に拠るものでは あろうが，その根本は現実の「水」そのもの以外ではないのである。 あらゆる観念が現実にその根を持つものであるならば，吉野の川の流 れに氷遠を「見た」のと類似して，こういう観念が水と結びつくのは 水が滾々と湧いて止まない、そういう水の永遠性が根柢にあるという ことなのであろう。

大きく迂回して文献に現れる全ての水神と，井泉に託された意味を みてきたわけである。井泉のほとりは祭場であり，衛や市と同様歌垣 の行われる境界領域であった。井泉のほとりが祭場とされたのは，そ の「井」や「泉」, 即ち「水」の中に「見え」ない神を「見た」ことに 始まったものであろう。神という言葉に抵抗を感じるなら，氷遠性な り，神秘性なりを「水」に「見た」と言い換えても一向に差し支えは ない。どのように言い換えようが, 井泉は神出現の場であり, 人知を 超えた神なるものに出会える場所，神なるものを「見る」ことが可能 
な場所として先ずあったのである。神なるものと出会える場所は同時 に, 互いに見知らぬ人間同志が出会うべき境界的, 即ち無記なる場所 でもあったということなのである。

\section{IV. 二つの場所・彼方と此方}

藤井が原と吉野，この二つの場所はどのように構造化されればよい のであろうか。持統の吉野行幸に従駕した二人に拠る，吉野宮での詠 み歌を引用しよう。

太上天皇、吉野宫に幸す時に、高市連黑人の作る影

大和には 鳴きてか来らむ 呼子鳥 象の中山 呼びそ越ゆなる $($ 巻- - 七

吉野宮に幸す時に、弓制皇子、頪田王に贈り与尔る歌一首

古に 恋ふる鳥かも ゆづるはの 御井の上より 鳴き渡り行く

いずれも藤原京に居る想い人への贈答歌である38)。山塊に拠つて隔 てられた此方と彼方は，地表に否応なく縛り付けられている人間にと っては，実際の距離以上に遠い。その上緀々みてきた如く，吉野とい う場所が他の場所と異なった別世界と観念されていたのであれば二つ の場所は，互いに隔絶しているとすら感ぜられていたであろう。私的 な感情を抱いていた詠み手にとっては絶望的に壹かったに違いないの である。ところが, 恐らくこのように意識されていたであろう両場所 の距離は，大空を飛翔する鳥たちにとっては易々と越えられるもので あることが, 即ち鳥たちにとって二つの場所などという概念そのもの が, そもそも問題とならないものであろうことが羡望されているので ある。二つの場所が同じ地表上に存在する限り, 地表を覆う天空が連 続するのは当たり前の話ではある。ここで問題とされるべきは二つの 場所の, 平面的・物理的距離ではなく, 空間的且つ意識的, 謂わば 「生きられ」た距離なのである。即ち，地表に於いては遠く，天空に於 いては近いものと意識されていたと言い得ようか。それでは地表面の 下に於ける事態は如何であろうか。ところが残念ながら, 当時の吉野 と藤井が原を地下に於いて結びつける直接の史料はないと言わねばな らない。だが, 都が奈良に遷って暫くして始まり ${ }^{39}$, 現代に於いても 営々と受け継がれている非常に注目すべき行事がある。有名な東大寺 二月堂の修二会に於ける「お水取り」がそれである。若狭の海にそそ ぐ遠敷川の水が, 遠い空間を隔てて東大寺二月堂の斜面の下の閦伽井 屋の中に掘られた「若狭井」に流れくる。その水を「關伽水」又は 「香水」と呼びこれを汲む行事が謂わゆる「お水取り」であることは説 明を要しないであろう。この行事が神道に由来するものであるか，陰 陽思想或いは仏教思想に基づくものであるのかについての穿盤はここ では無用である。注目すべきは，それが例え年に一度のことであって も，彼方の「水」が此方の「井」にあると信じられていることである。 「井」から離れた場所の「水」が湧き出すということは, 地下に於いて 水路が慗がっているという幻想とも言うべき確信がその根底に存在し ているものと思われる。このように理解すれば, 先述の座摩巫の井の 三神の一神「津長井神」が「地下に伏道ありて、遠くその脈より来り て溜る由なり。然れば、井泉の神なる事云ふも更なり4り」と説かれて いたことも肯けるものとなるのである。

このような幻想は幾例か揭げられるのであるが41，次にやはり吉野 と大和に関する事例をみておかなければならない。それは同じく現代
に受け継がれる「大汝参り」という民間信仰である。上市のすぐ東に 吉野の妹山があり，この山に式内社大名持神社が祭られている(2)。こ の神社のすぐ前を流れる吉野川の淵を, 古来より潮生淵と呼ぶ。その 名は毎年旧暦の六月䀲日に, この潮生淵から熊野の潮水が湧き出ると 信じられていることに由来するという43》。この潮生淵で「水垢離」即 ち裙ぎを行い，河原の石を拾い，水を汲んで持ち帰る。そうして持ち 帰った水を自分たちの村の川に流し，一同がその水で裙ぎをすると言 う。これが「大汝参り」の習俗のあらましであり, 香久山周辺の村々, 耳成山口神社の宮講4)を含む国中や宇陀郡までの大和南部地域で信仰 されている。またほぼ同じ主旨の祭儀が靯傍山口坐神社に於いても行 われていることを見逃してはならない45)。或いは「再生をたくす『変 若水(5)』の祭儀であろう」かとも論ぜられたりしているが，この祭儀 が何を目的とするものかは必ずしも明らかではないようであるが，そ れでも大和三山と吉野とが, そしてここではさらに熊野と吉野とが 「水」に拠つて慗がっていることを想わせるに十分な事例としてあり得 るであろう。この事例に於いては, 熊野の「水」が吉野を経由し, 人 の手を借りて大和へと運ばれるのであるが, 元々は熊野とは無関係に, 吉野の「水」が人の手を借りるまでもなく大和へ流れ込んでいたと幻 想されていたものと思われる。

いずれにせよこれらの例に於いて，それぞれ彼方の「水」は年に一 度, 遠い距離をものともせず, 大和に流れ来たりて湧き出ずるのであ る。互いに距離を隔てた二つの場所が「水」に拠って連続する。その 時, 大和の「水」は即吉野の「水」なのであり, 若狭の「水」なので ある。そ㧈はとりもなおさず, 二つの場所そのものがびたりと一つに 重なるということを言うに他ならないのである。即ち, その刹那, 大 和は吉野であり熊野であり, 若狭なのである。そこでは最早流れ込む とか, 地下水路が云々であるとかの理屈は全く意味を為すものではな く, 遠い近いという距離概念すらも無効なのである。ただ端的に重層 する。我々にしてみれば幻想と呼ばざるを得ない現象であったとして も, それを「生きた」人々にとって, 幻想は幻想の儘, 厳然たる事実 なのである。空間は均質ではなく, 融通無碍に伸縮するという言い方 が相当する事例であろう

遠く隔たつた彼方と此方は「水」に拠って，「水」を介して重層す ることが司見きられたのである。藤原の「御井の水」と吉野川の「水」, つまり藤井が原と吉野という二つの場所についても同様の構造の存在 が予想されもしようが, 結論を下すのは以下の幾つかの問題を考察し た後になされなければならない。

「井」や「泉」が境界であるということ，そしてそれらの場所に神 なるものを「見た」痕跡の確認がなされた。即ち, 神出現の場として 「井」や「泉」があったことが確認されたとしてよいものと思われるが、 そこには新たに, その神なるものはどこから, そしてどのように現れ るのであろうかという疑問や, 或いは境界とは言うもののそれは具体 的にどことどこの境界であるのか，さらに，如何にして「井」や「泉」 は境界足り得たのか, 何故その「水」は「井」や「泉」から湧き出す 冰」でなければならなかったのであろうか等々という疑問が生じてい るからである。こうした観点から再度「井」に関する伝承を検討して みよう。先ず若干極端とも思われる神話時代の「井」を見てみよう47。

……其綿津見神之宮者也。到_其神後門_者、傍之井上、有_湯津香木。故、

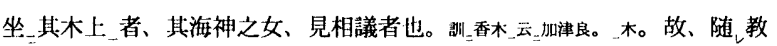


少行、備如_其言_、即登_其香木_以坐。爾海神之女、豐玉昆賣之從婢、持

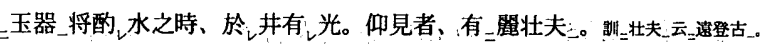
下效此。

( 「古事記」上巻，海神の宮訪問」)

火遠理命の海神の宮訪問譚である。ここでも「井」は神出現の場と して，神と出会う場として重要な意味を担うものである。それは「水 に写る影を見て樹上の者に気づく有様は、水中から火遠理命が出現し たことと少しも変わりはない到」からである。さらに例を重ねよう。 前稿で既に触れた吉野の「井」である。ここでは『古事記』から引用 しておくこととしよう。

從_其地_幸行者、生、尾人、自々井出來。其井有、光。爾問_汝者誰也、 答一三僕者國神、名謂_井水鹿_。此者吉野首等祖也。

(古事記」中巻 神武天皇東征条)

ここに登場する吉野首の祖とされる「井水鹿」は，先述したように その姿は尾がある異形に描かれてはいるが，「其井有、光」と記されて いるように，一面に霊威を持つ「國神」である。そして「井」に関わ る神であることから, やはり「泉井の神なのであろう る神である。この例では先の火遠理命の例よりはるかに明確に，神た る「井水鹿」は「井」の中から出現するのである。既に我々は，この 二例以外にも井泉の辺に，或いは吉野川のほとりに，神なるもの以外 に, 天女や仙女といった人ならざるものが出現する，若しくは出会う という事例をみてきた。これら全ての例は，水に関する神に限らず， 人ならざるものは水を通って顕現するという確信が存在していたこと を物語るものと言えるのではなかろうか。そして人ならざるもの出現 の場所として「水」のほとりが際立つのは；それは神なるものが潜む 場所ではなく，人間世界と隔絶した，神なるものの世界や常世の国， 或いはあの世といった「彼方」への出入口と解釈してその意味は十全 なものになるのではなかろうか。人ならざるものの世界と人間世界と の接点が井泉なのである。人ならざるもののみが交通可能である「水」 そのものが, 異界との通路として，そこへ接する境界的な存在であり， 「此方」には他界の表象として「井」や「泉」があったのである。

\section{V. 結 一吉野と藤井が原}

本節は本稿の結論として,ここまでに得られた全ての知見を綜合し， 藤井が原と吉野という二つの場所の構造化を試みるものである。この 試みは同時に，藤原京の風景の全体構造が素描されることともなろう。 風景論という本稿の立場から知見の組み替えが試みられるのである。

前稿では二つの場所の関係が，境界としての「水」との関わりの中 で論じられた。そこでは既に、「彼方」「此方」という概念が導入され ていたのであるが，それは未だ暧昧な儘での使われ方であった。本節 では,「此方」を藤井が原に固定し「彼方」である吉野との関係構造の 定着を試みる。この試みは同時に，自ずと五二番歌に吉野が詠み込ま れる必然性の解明の試みともなるであろう。「此方」を藤井が原に想定 するということは, 「御井歌」の詠われ方に即す,つまり視点, 意識の 在りどころとして藤井が原を想定することに他ならないのである。こ の想定は言い換えれば，そこに「見え」る限りの範囲が，即ちたたな づく青垣の「内」なる大和盆地(南部)が, この歌の作者及び天皇に代 表される都人にとっての第一の，そして唯一の地平であるということ を承認することを意味することとなるであろう。そしてそうした地理
的拡がりの一部である藤井が原という領域は藤原京の造営と相即して 「内」なる場所として，さらに細分節，再限定されたのである。些か模 式図的ではあるが，「内」なる大和の「内」なる藤井が原として，同一 平面上に同心円構造を想い描けばよいであろう。この再限定の事情は， 前稿らに於いて詳しく論述されたように; 限定は三山と吉野に拠って， 恰もそこに「見え」ない限定面が設定されるかの如くなされていたの であった。大和三山が「門」を表示することに拠って，境界の標示と して在ったのである。藤井が原という場所はこのような二重の限定に よって「内」の「内」なる場所として地平の上に「図」として浮き彫 りとなるのである。つまり藤原京という現実世界はこのように構造化 されたのである。さらに言い換えれば藤原京という場所，即ち安らげ る生活世界がそこに「開か」れて在るのである。地表上のあらゆる場 所が構造化されているわけではないが，人は場所を構造化しつつ「生 き」るしかないのである。

この「藤原宮御井歌」は藤原京という場所が「開か」れたことを高 らかに詠い上げるものに他ならず，宮と王権の永遠なることを願うこ とは,この安んじてある「開かれ」た場所の常久なることを願うもの に他ならないのである。既にみた儀礼・祭式と同じく，放置しておく と閉塞し「外」なる場所へと解消せんとする必然への，有限を「生き」 るものの；それはせめてもの抵抗なのでもあろう。

地表がこのように「内」「外」なる場所として構造化されるという 考え方からすれば，藤原京という世界はひとまずは完結した世界と考 えられよう。ところが言うまでもなく，全く他と絶縁して独立完結す る世界はないのである。つまり「外」なる場所との関係に於いて，「外」 があって初めて境界というものが意味を持ち「内」なる場所が成立す るのである。この周りの事情については，門」に於いて特徵的であつ た境界の両義性のこととして既に考察されたところである。完結して いるかに「見え」る世界はその完結を許容し支える，より大きな「地」 としての地平に於いて在らねばならないのである。それではこの限定 面の「外」は如何なる状況にあったのであるかというと，三山という 「門」を通して無限の「彼方」に連なり行くものであろうとしても，こ れらの「門」の「外」側は未だ大和の「内」なる場所，つまり「内」 なる「外」と考えるべきであろう。これに対し，現実には龍門山塊を 指すものと思われる「吉野の山」と表記された南の境界面は「内」な る場所を「内」なる場所と「見せ」る「内」なる限定面として在りな がら同時に，「外」なる領域の「外」なる限定面としても現象していた と考えなければならないのである。南に一山越えた吉野という場所は, 最初から「内」なる場所ではなく完全に「外」なる場所と考えられて いたであろうことはこれまでの考察から断じてよいからである。山の 向こうに在る吉野という場所は,「此方」である藤井が原とは別の場所, 異なった原理が支配する別の地平として「彼方」と呼ばれるに相応し い世界，即ち他界であったのである。吉野が「彼方」として在り得た のは，そこが人を超えたものの「住む」世界であり，人を超えたもの たちの世界へのと通じる「水」の在処であると信じられていたからに 他ならない。大和世界を唯一の地平として考える時, その「外」側に 在るべき吉野世界が，このようにそれ自身の地平に「開か」れたもの である限り，吉野は「どうしても『内』にならない『外』つまり「絶

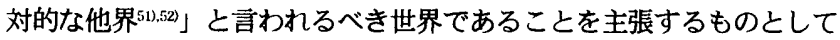
在るであろう。「彼方」とは単に距離か離れていることに拠るものでは ないのである。吉野は最早単に「外」と言われるべきでもなく，藤井 が原と同位に並ぶ独立した世界でもあり得ないのである。同位でない 
とする理由は意識の所在が藤井が原にあるからに他ならないのである が，だからといって吉野が劣位に置かれていると考えるのは早計であ ろう。なぜなら縷々みてきたところから明らかなように, 吉野なくし て藤原京は成立しないとまで思わせるほどに重要な場所として吉野は 在ったからである。

それではこれら以外にどのような解釈が可能であろうか。本稿は両 場所の構造化解明は，やはり「水」に拠ってなされるべきであろうと 考えるものである。即ち，「水」が境界であり通路であったこと，さら に「御井歌」がその標題と構成そのものに於いて「井」を讃えていた ことは, 彼らの「住ま」う藤井が原と吉野が直に連䌇することが願わ れ，且つ信じられていたことを如実に示していると思われることに拠 る。そしてこの連続とは, 同一の地平の上での連結というょうなもの ではなく，吉野は藤井が原という地平をその下面から裏打ちを成すか のように重なっている，或いは現実の生活世界である藤井が原という 地平を吉野という人知を超えた無限の地平が，恰も同心球の如くに全 方位から包み込んでいると考えるべき事態であると思われる。二つの 世界は互いにその位相を変えて論じられなければならないのであり， 殊更に「地平」という概念を導入した理由はここにあるのである。要 するに，藤井が原という地平を「生きる」意識は同時に，遠い「彼方」 の吉野の地平をも「生き」ているのであり，「藤原宮御井歌」に詠み込 まれた「御井の真清水」こそが, 吉野と藤井が原を重ねる紐帯そのも のなのである。大和三山を「門」と解釈したことの連関から，この 「御井」を神なるものとその世界を覗き「見」る「空」とみる解釈は如 何であろうか。神なるものとその世界は決して直接眼にすることの出 来ないものであった。だがそうであるからこそよけいに「御井」の水 面という「空」を通して透かし「見る」ということが希求されていた のではなかろうか。「見た」いと欲せられたものは言うまでもなく吉野 世界であり，「御井歌」に現実には「見え」ない吉野が詠われていた理 由も，この透かし「見」の対象としてではなかったのであろうか。「彼 方」の吉野を瞀き「見」る「空」が即ち「御井」であり，遠い「彼方」 は,「御井」の底深く, 即ち足下に重なっているのである。「天は足下 にあり」と語った神秘主義的哲学者が想い起こされもする。

人は世界の多重性，地平の多層性を「生き」るものであり，ここに 縷々論じてきたあらゆる構造が風景として「生きら」れ，その全てが この「御井歌」に結晶していると結論づけるのは果たして解釈の過剩 であろうか。

註

1）拙稿：(1)「吉野の風景「藤原宮御井歌」にみる風景の構造 II」，日本建築 学会計画系論文報告集 第511号, pp.217 222, 平成10年9月

2）「藤原宮御井歌」の考察は本稿を以て一応の完結をみることとなる。

「御井歌」を三段構成と捉え，その第一段は「見したまへば」に注目 し, 古代特有の視覚の問題として国見儀礼への着目の中に（2)「古代 日本の風景?国見儀礼」にみる視賞の構造」，日本建筑学会計画系論文報 告集 第511号) 論考された。第二段は，大和三山と吉野に分割され それぞれに解秎が与えられた（3）「大和三山の風景「藤原宮御井歌」に みる風景の構造」，日本建築学会計画系論文報告集 第 480 号，及び上揭 した拙稿である)。本稿は，上掲した拙稿の続編であり，第二段の 「吉野」の意味が第三段「御井」の意味付けの中に綜合される。従つ て(3)(2)，そして本稿の順に通読されることを希望する。

3）澤渏久孝: 萬葉集注釋巻第一,p. 351 ,昭和 32 年 11 月,中央公論

4）土橋寛：「藤原宮」の宮号の由来一二つの<藤原〉をめぐって一,萬葉集 の文学と歴史 土橋寛論文集 上,p.29,昭和63年6月,塙書房

5）同上 : p.31

6）伊藤博：萬葉集釋註 一,p.226,平成7年11月,集英社

7）この歌と関連して以下の歌を引用しておく。

やすみしし わご大君 高照らす 日の御子の 閶こし食す 御食つ国 神風の 伊勢の国は 国見ればしも 山見れば 高く貴し 川見れば さやけく消し 淃な
す 海も広し 見度す 島も名高しここをしも まぐはしみかも かけまくも あやに恐き 山の辺の 五十師の原に うちひさす 大宮仕へ 朝日なす まぐは しも 名はす うらぐはしも 春山の しなひ栄えて 秋山の 色なつかしき ももしきの 大宮人は 天地と 日月と共に 万代にもが

反 山辺の 五十師の御井は おのつから 成れる錦を 張れる山かも (巻十シーシニシ五)

十二月壬午蝴丙成、侍二奉大曾一中臣・忌部及神官人等、并播磨・丹波、二國郡司、 亦以下人夫等、悉賜、淥。因以郡司等、各賜_爵一級。( 三月甲戍朔壬午、於山御井傍、敖諸神座、而班幣帛。中臣金連宣、祝詞。

(阳本書紀! 天智天皇九年三月)

10）『延喜式 巻第七 神祇七』

11）「大嘗祭における「御井」のト定は、平安朝の『儀式』や『延喜式』 に見えるものではあるが、大暮に際して悠紀・主基二国のト定その他 に中臣・忌部及び「神官人等」が奉仕することは、すでに「天武紀」 二年十二月丙成条その他に見えているから、「御井」のト定も天武朝 に行われていたと見てよい(土橋寛 : 中臣寿詞と持統朝,日本古代の呪融と説 話 土楿寛論文集 下,p.342,平成元年10月，缡書房)」という説を支持するもの である。また『踐祚大嘗祭式』に拠れば, 大覃祭の斎部の斎場と在京 の斎場の二ヶ処に斎場が設営され，それぞれに井戸が㗇られたことが みえるが，「(二ヶ処の章場は)もともと同じものの分化した形であろうと 思われる(松前健 : 古代伝承と宫廷祭祀,p.57,昭和49年4月，埥畫房)」のであり, 藤原宮に於いては，その井戸は宮域に掘られたと考えてもよいものと 思われる。

12）以。當郡大小領女米嫁卜食者 充之

(「延䣒式」巻第七神话七）

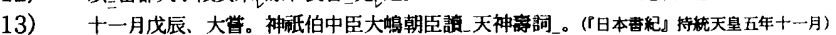

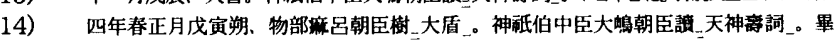

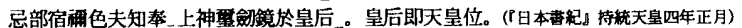

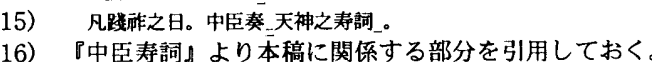

中臣, 遠都祖天兒屋根命、皇御孫尊 $n$

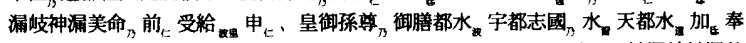

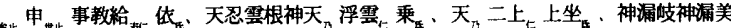

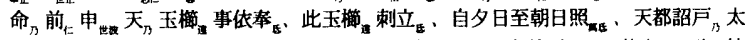
詔刀言 以 天都水、所開食，事依奉。

17）前掲11)松前論文,pp. $62 \sim 63$

18）岡田精司：大王と井水の祭儀,講座 日本の古代信仰 第 3 巻 呪ないと祭 り,pp.198〜 199,昭和55年2月，學生社

19）ここに要的するのは勿論『祈年祭祝詞』であるが，『月次祭祝詞』に もほぼ同様の詞句がみられる。

20）祝詞では「生井・榮井・津長井の神」と見える。また『神道大辞典』 に拠れば，この三神は順に，流水・醴泉・井泉を各々掌り分かち守る とされる。

21）土橋寛：「藤原宮御井歌」の特異性と中臣氏,萬葉集の文学と歴史 土 橋寛論文集 上,p.36,昭和63年6月,㙵書房

22）因みに，平安京内裹に於ける御井の位置は豊楽院の西，典薬寮の南で ある。

23）御川水祭座摩巫各行, 事。（「延喜式」卷一神试一四時祭上

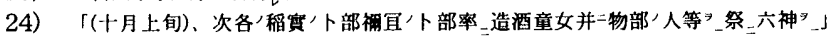

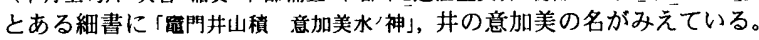
(「貞暊儀式」卷第三 踐看大當祭儀 中)

25）『古事記』には「淤迦美神」と表記され，『日本書紀』では「霞」である。

26）前提21)で,「この「山御井」は三井寺の金堂の㥬らにある御井だとす るのが『日本書紀通証』以来の通説」であることが触れられている (p.36)。

27）同上

28）井泉に関する説話の全てをここに引用するべきではあろうが，紙幅の 都合上本文に引用できなかったものを，以下に列挙しておく。常陸国 風土記」「總記」・衣袖清の井／「茨城郡条」・多余の清井：「播磨国風土記」 「揖保郡条」・宗我富の井/「揖保郡条」・流井、酒井、針間井/「讃容郡 条」・大の村の御井/「託賀郡条」・都麻の井/「賀毛郡条」・佐々の井

29）また家持には，同じ越中国司時代雨乞いの長短歌(巻一八一四-二二〜 三)と，その結果の降雨を賀く歌(巻一八一四一二四)が伝わっている。天 皇と同様雨乞いが国司の職務であったのであろうか。また四-二-・番 歌に「天つ水 仰ぎてそ待つ」という詩句があることを付記しておく。 30) 前揭2),拙稿(3), p.199 200

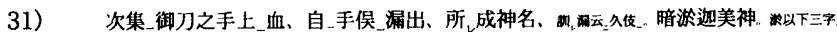

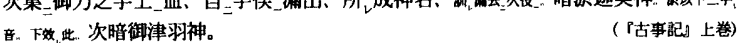
複劍頭垂血、激越為、神。躆日暗震_。次暗山的。次暗圆象。

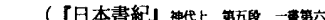

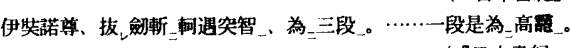

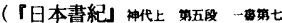

また『萬葉集』には以下の歌が収められている。

萑原夫人に和慗亏一首

我が岡の 蹗に言ひて 降らしめし 雪の研けし そこに散りけむ（巻ニ---OO四） 次於、尿成神名、憡都波能賣神

( 古事記 上巻) 


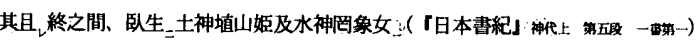
一昦第三第四もほぼ同様。

33）『古事記』，「日本古典文学太系」,頭注一 $0, p .60$, 『日本書紀』，「日 本古典文学大系」,頭注三三,p.89

34）前揭2), 拙稿(3)

35）、青木紀元 : :日本神話の基礎的研究,pp.4 5,昭和58年5月,風間書房

36）前稿（前掲2），拙稿(3）で香久山も水と関係するとした根拋である。

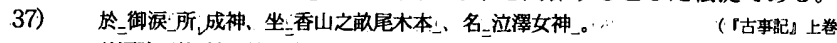

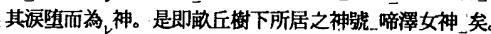

38)

一一一番歌は次の返し歌を持つ。

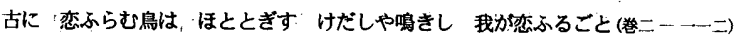

39）『東大寺要録』に拠ると，その始まりは天平勝宝(752)四年であると されている。

40). 神道大辞典, $\mathrm{p}: 1305$,昭和 13 年7月,臨泉書店

41），同様の例を一例だけ掲けておく。「高天原の武神タケミカズチとカく らへをした出雲の軍神夕ケミナカ夕をまつる諏訪神社上社の提社、葛 ，井神社はあきらかに「葛井の池」とよばれる棈円形の池を神体とした 、社であるが、伝承に、上社で使った一年中の御幣を大䀲日の夜にこの 池に捨てると、翌朝遠州のさなぎの池に浮かび上がるといい、䯅訪の 七不思議の一つと称している。この遠州のさなぎの池とは、今日浜松 市西方の佐鳴湖とされており、湖畔にある竜雲寺の木宮住職の話では 近くの弁天祠の池の底は諏訪湖の底と通じている、という伝承がある とのことである。(金井典美 : 湿原祭祀一整䝠の信仰と文化一,p.25,昭和50年12 月,法政大学出版局)」

42）『三代実録」「貞観元(859)年正月甘七日采」に，祭神「大己貴神」を祭る 記事がある。

43）前登志夫 : 吉野紀行 新版,pp.59 60,昭和59年3月,角川書店
44） 池田源太：大和三山;p:134,昭和47年4月，學生社

45）同上：p.113,「お峯山の水取り」，と呼ばれる畧傍山口坐神社の代表的 祭り。七月二八，九日に行われる「お峯の゙デソソうに付随する故実 三八日（現在は二六日）の早朝宮司が吉野川へ水を汲みに行く行事で ある。

46）千田稔：吉野風景論一文芸者たちの<地図〉一,吉野地域における文化的価 值の再点検と信仰のための調查一昭和五十八年度報告费一財団法人 文化 研究所,p.58,昭和 59 年 3 月

47）本文には『古事記』を引用したが『日本書紀』の該当部分を以下に引 用しておく。

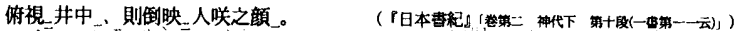

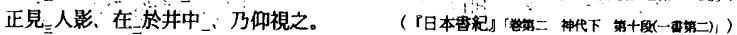

48）引木倛侑 : 水伝承,シリーズ 古代の文学 5 伝承と変容,p.84,昭和 55 年 2 月 武藏野書院

49）松前健; 総説,大阪成蹊女子短期大学国文学研究室編 吉野の文学,p.5,平成4 年6.月,和泉書院

50) 前掲2)，拙稿(3)

51）小松和彦：異人論一民俗社会の心性,p.243;昭和60年7月,青土社

52）同上論文で小松も「内」と「外」の関係はやはりレウェルルに応じて変 化することに触れているが，吉野に託されていた他界の観念もやがて， 時代とともにさらに山を越え熊野へと及んでいくことになるのであ る。

尚，「古事記」「日本書紀」「綍日本紀」「祝詞」「風土記」，の引用は新旧岩波古典文学大 系本に、「代実録」「日本後紀」延喜式」「令義解」については吉川弘文館新訂增補国 史大亲本にままだ律令」は岩波日本思想大系本，「貞観儀式」は現代思潮社版螋日本古 典全集本をそれぞれ参照した。「萬葉集」については缡書房版「萬葉集」訳文篇からの引 用である。 